\title{
Synthesis, Structures, and Reactions of Dirhodium Complexes Bearing a 1,2-Diphenyl-3,4-diphosphinidenecyclobutene Ligand (DPCB)
}

\author{
Masaaki Okazaki, ${ }^{\star \dagger}$ Akito Hayashi, ${ }^{\dagger}$ Ching-Feng Fu, ${ }^{*}$ Shiuh-Tzung Liu, ${ }^{\ddagger}$ and \\ Fumiyuki Ozawa*, \\ International Research Center for Elements Science, Institute for Chemical Research, Kyoto University, \\ Uji, Kyoto 611-0011, Japan, and Department of Chemistry, National Taiwan University, \\ Taipei, Taiwan 106, Republic of China
}

Received November 11, 2008

\begin{abstract}
A di- $\mu$-hydroxo-dirhodium complex bearing a low-coordinate phosphorus ligand, $\left[\mathrm{Rh}_{2}(\mu-\mathrm{OH})_{2}(\mathrm{DPCB})_{2}\right]$ (2; DPCB = 1,2-diphenyl-3,4-bis[(2,4,6-tri-tert-butylphenyl)phosphinidene $]$ cyclobutene), is prepared from $\left[\mathrm{Rh}_{2}(\mu-\mathrm{Cl})_{2}(\mathrm{DPCB})_{2}\right](\mathbf{1})$ and $\mathrm{KOH}$. Complex 2 serves as a good precursor for hydrido complexes, affording $\left[\mathrm{Rh}_{2}(\mu-\mathrm{H})(\mu-\mathrm{OH})(\mathrm{DPCB})_{2}\right](3)$ and $\left[\mathrm{Rh}_{2}(\mu-\mathrm{H})_{2}(\mathrm{DPCB})_{2}\right](7)$ by the reactions with $\mathrm{HSiMe}_{2} \mathrm{Ph}$ and $\mathrm{HCO}_{2} \mathrm{H}$, respectively. Although complex $\mathbf{7}$ is too unstable to be isolated, its formation is evidenced by a trapping experiment using 1,3-cyclohexadiene to give $\left[\mathrm{Rh}\left(\eta^{3}-\mathrm{C}_{6} \mathrm{H}_{9}\right)(\mathrm{DPCB})\right](\mathbf{8})$. Complex 2 reacts with $\mathrm{CO}$ to afford $\left[\mathrm{Rh}_{2}(\mu-\kappa P, P ; \kappa P, C\right.$-DPCB $\left.)(\mathrm{CO})_{4}\right](\mathbf{9})$ and $\left[\mathrm{Rh}_{2}(\mu-\mathrm{CO})_{2}(\mathrm{DPCB})_{2}\right](\mathbf{1 0})$, which are interconvertible in solution. Complex 9 is the stable form under a $\mathrm{CO}$ atmosphere even in the presence of free DPCB, but readily converted to 10 by purging the $\mathrm{CO}$ gas from the solution. The $\mathrm{X}$-ray structures of $\mathbf{2}, \mathbf{3 , 9}, \mathbf{1 0}$, and related $\left[\mathrm{Rh}_{2}(\mu-\mathrm{H})(\mu-\mathrm{OMe})(\mathrm{DPCB})_{2}\right](\mathbf{4})$ are reported. Two $\mathrm{Rh}(\mathrm{DPCB})$ moieties in $\mathbf{1 0}$ are oriented orthogonal to each other in the crystal; namely, one of the Rh centers has a square-planar configuration, whereas the other is in a tetrahedral arrangement with the $\mu$-CO and DPCB ligands, showing flexible electronic properties of DPCB.
\end{abstract}

\section{Introduction}

There has been considerable recent interest in the coordination chemistry of low-coordinate phosphorus compounds due to their unique ligand properties, differing significantly from common tertiary phosphanes. ${ }^{1}$ Phosphaalkenes having a $\mathrm{P}=\mathrm{C}$ double bond are among the central subjects in such chemistry. ${ }^{2}$ The $\mathrm{MO}$ calculations on carbon monoxide $(\mathrm{C} \equiv \mathrm{O})$, phosphaethene

* To whom correspondence should be addressed. E-mail: (M.O.) mokazaki@scl.kyoto-u.ac.jp. (F.O.) ozawa@scl.kyoto-u.ac.jp.

Kyoto University.

$\doteqdot$ National Taiwan University.

(1) (a) Le Floch, P. Coord. Chem. Rev. 2006, 250, 627. (b) Yoshifuji, M. Pure Appl. Chem. 2005, 77, 2011. (c) Mathey, F. Angew. Chem., Int Ed. 2003, 42, 1578. (d) Weber, L. Angew. Chem., Int. Ed. 2002, 41, 563.

(2) (a) Deschamps, B.; Le Goff, X.; Ricard, L.; Le Floch, P. Heteroat. Chem. 2007, 18, 363. (b) Masuda, J. D.; Martin, D.; Lyon-Saunier, C.; Baceiredo, A.; Gornitzka, H.; Donnadieu, B.; Bertrand, G. Chem. Asian J. 2007, 2, 178. (c) Ionkin, A. S.; Marshall, W. J.; Fish, B. M.; Schiffhauer, M. F.; Davidson, F.; McEwen, C. N.; Keys, D. E. Organometallics 2007, 26, 5050. (d) Nakamura, A.; Kawasaki, S.; Toyota, K.; Yoshifuji, M. J. Organomet. Chem. 2007, 692, 70. (e) Mézailles, N.; Le Floch, P. Dalton Trans. 2006, 594. (f) Ito, S.; Freytag, M.; Yoshifuji, M. Dalton Trans. 2006, 710. (g) Freytag, M.; Ito, S.; Yoshifuji, M. Chem. Asian J. 2006, 1, 693. (h) Ito, S.; Nishide, K.; Yoshifuji, M. Organometallics 2006, 25, 1424. (i) Gouverd, C.; Brynda, M.; Berclaz, T.; Geoffroy, M. J. Organomet. Chem. 2006, 691, 72. (j) Kawasaki, S.; Nakamura, A.; Toyota, K.; Yoshifuji, M. Organometallics 2005, 24, 2983. (k) Boubekeur, L.; Ricard, L.; Le Floch, P.; Mézailles, N. Organometallics 2005, 24, 3856. (1) Nishide, K.; Liang, H.; Ito, S.; Yoshifuji, M. J. Organomet. Chem. 2005, 690, 4809. (m) Martin, D.; Baceiredo, A.; Gornitzka, H.; Schoeller, W. W.; Bertrand, G. Angew. Chem., Int. Ed. 2005, 44, 1700. (n) Nakamura, A.; Kawasaki, S.; Toyota, K.; Yoshifuji, M. Chem. Lett. 2004, 33, 1570. (o) Liang, H.; Ito, S.; Yoshifuji, M. Org. Lett. 2004, 6, 425. (p) Ionkin, A.; Marshall, W. Chem. Commun. 2003, 710. (q) Moores, A.; Mézailles, N.; Ricard, L.; Mathey, F.; Le Floch, P. Chem. Commun. 2003, 1914. (r) Spencer, L. P.; Altwer, R.; Wei, P.; Gelmini, L.; Gauld, J.; Stephan, D. W. Organometallics 2003, 22, 3841. (s) Daugulis, A.; Brookhart, M.; White, P. S. Organometallics 2002, 21, 5935 .
$\left(\mathrm{H}_{2} \mathrm{C}=\mathrm{PH}\right)$, imine $\left(\mathrm{H}_{2} \mathrm{C}=\mathrm{NH}\right)$, and phosphane $\left(\mathrm{PH}_{3}\right)$ have shown that the $\pi^{*}$ orbital level of the $\mathrm{C}=\mathrm{P}$ bond is much lower than those of $\mathrm{C} \equiv \mathrm{O}$ and $\mathrm{C}=\mathrm{N}$ bonds. ${ }^{3}$ On the other hand, the lone-pair orbital of phosphaethene is situated at a comparable level to that of phosphane. Accordingly, phosphaalkenes undergo strong $\sigma$-donation and $\pi$-back-donation interactions with transition metals. We have demonstrated using 1,2-diphenyl-3,4bis[(2,4,6-tri-tert-butylphenyl)phosphinidene]cyclobutenes (DPCB$\mathrm{Y}$; Y stands for the $p$-substituents of 1,2-diphenyl groups) that this ligand property is useful for catalysis, leading to highly efficient organic transformations in conjunction with group 8 and 10 metals. $^{4,5}$

In this study, we synthesized several organorhodium complexes bearing DPCB ligand $(\mathrm{Y}=\mathrm{H})$ and examined their structures and reactivities. A particular interest has been focused on hydridorhodium complexes, because hydrido species have often been observed as key intermediates in DPCB-Y complexcatalyzed reactions. ${ }^{4}$ For their preparation, we employed the rhodium hydroxide $\left[\mathrm{Rh}_{2}(\mu-\mathrm{OH})_{2}(\mathrm{DPCB})_{2}\right]$ as a common precursor. In the past several decades, a great deal of attention has been focused on hydroxo complexes of late transition metals, because of their interesting reactivities and potential relevance to catalytic reactions. ${ }^{6}$ For example, $\mathrm{M}-\mathrm{OH}$ species often react with organic compounds with acidic nature, along with only by-production of $\mathrm{H}_{2} \mathrm{O}$. Thus, hydroxo complexes may serve as clean and versatile precursors of a variety of complexes. ${ }^{7}$ The synthesis and reactions of rhodium hydroxides have been

(3) Ozawa, F.; Kawagishi, S.; Ishiyama, T.; Yoshifuji, M. Organometallics 2004, 23, 1325.

(4) (a) Ozawa, F.; Yoshifuji, M. Dalton Trans. 2006, 4987. (b) Ozawa, F.; Yoshifuji, M. C. R. Chim. 2004, 7, 747. 
examined with tertiary phosphanes as ancillary ligands. ${ }^{8-11}$ However, most of them are highly air-sensitive even in the solid state, probably due to high electron density of the metal centers. Accordingly, despite their utility, the study of hydroxorhodium complexes has remained insufficiently explored. On the other hand, we found that the DPCB ligand successfully stabilizes rhodium hydroxide without notable loss of the reactivity.

\section{Results and Discussion}

Synthesis of $\left[\mathrm{Rh}_{2}(\mu-\mathrm{OH})_{2}(\mathrm{DPCB})_{2}\right]$ (2). DPCB was introduced to rhodium by ligand displacement with $\left[\mathrm{Rh}_{2}(\mu-\right.$ $\left.\mathrm{Cl})_{2}\left(\mathrm{C}_{2} \mathrm{H}_{4}\right)_{4}\right]$ in toluene at room temperature (Scheme 1). Treatment of 1 with aqueous $\mathrm{KOH}$ in toluene at $80{ }^{\circ} \mathrm{C}$ formed $\left[\mathrm{Rh}_{2}(\mu-\mathrm{OH})_{2}(\mathrm{DPCB})_{2}\right](\mathbf{2})$, which was isolated in $98 \%$ yield as a dark yellow solid, fairly stable in air. The ${ }^{31} \mathrm{P}\left\{{ }^{1} \mathrm{H}\right\}$ NMR signal appeared at $\delta 164.1$ as a doublet with the ${ }^{1} J_{\mathrm{RhP}}$ coupling of 244 Hz. The ${ }^{1} \mathrm{H}$ NMR spectrum exhibited a singlet signal at $\delta-1.66$, assignable to $\mu$-OH protons; the chemical shift is comparable to those of tertiary phosphane analogues. ${ }^{8 \mathrm{c}, 9 \mathrm{i}, 10,11 \mathrm{a}}$ The signal instantly disappeared upon treatment with $\mathrm{D}_{2} \mathrm{O}$.

Figure 1 shows the crystal structure of $\mathbf{2}$, which has a center of symmetry at the intersection of $\mathrm{Rh}-\mathrm{Rh}^{*}$ and $\mathrm{O}-\mathrm{O} *$ vectors. Each rhodium center takes a square-planar geometry. The $\mathrm{Rh}-\mathrm{P}$ $(\mathrm{Rh}-\mathrm{P} 1=2.1879(12), \mathrm{Rh}-\mathrm{P} 2=2.1863(12) \AA)$ and $\mathrm{Rh}-\mathrm{O}$

(5) (a) Hayashi, A.; Yoshitomi, T.; Umeda, K.; Okazaki, M.; Ozawa, F. Organometallics 2008, 27, 2321. (b) Jensen, R. S.; Umeda, K.; Okazaki, M.; Ozawa, F.; Yoshifuji, M. J. Organomet. Chem. 2007, 692, 286. (c) Murakami, H.; Matsui, Y.; Ozawa, F.; Yoshifuji, M. J. Organomet. Chem. 2006, 691, 3151. (d) Katayama, H.; Nagao, M.; Nishimura, T.; Matsui, Y.; Umeda, K.; Akamatsu, K.; Tsuruoka, T.; Nawafune, H.; Ozawa, F. J. Am. Chem. Soc. 2005, 127, 4350. (e) Nagao, M.; Asano, K.; Umeda, K.; Katayama, H.; Ozawa, F. J. Org. Chem. 2005, 70, 10511. (f) Gajare, A. S.; Jensen, R. S.; Toyota, K.; Yoshifuji, M.; Ozawa, F. Synlett 2005, 144. (g) Jensen, R. S.; Gajare, A. S.; Toyota, K.; Yoshifuji, M.; Ozawa, F. Tetrahedron Lett. 2005, 46, 8645. (h) Ozawa, F.; Ishiyama, T.; Yamamoto, S.; Kawagishi, S.; Murakami, H.; Yoshifuji, M. Organometallics 2004, 23, 1698. (i) Murakami, H.; Minami, T.; Ozawa, F. J. Org. Chem. 2004, 69, 4482. (j) Gajare, A. S.; Toyota, K.; Yoshifuji, M.; Ozawa, F. J. Org. Chem. 2004, 69, 6504. (k) Gajare, A. S.; Toyota, K.; Yoshifuji, M.; Ozawa, F. Chem. Commun. 2004, 1994. (1) Ozawa, F.; Okamoto, H.; Kawagishi, S.; Yamamoto, S.; Minami, T.; Yoshifuji, M. J. Am. Chem. Soc. 2002, 124, 10968. (m) Minami, T.; Okamoto, H.; Ikeda, S.; Tanaka, R.; Ozawa, F.; Yoshifuji, M. Angew. Chem., Int. Ed. 2001, 40, 4501. (n) Ozawa, F.; Yamamoto, S.; Kawagishi, S.; Hiraoka, M.; Ikeda, S.; Minami, T.; Ito, S.; Yoshifuji, M. Chem. Lett. 2001, 972. (o) Ikeda, S.; Ohhata, F.; Miyoshi, M.; Tanaka, R.; Minami, T.; Ozawa, F.; Yoshifuji, M. Angew. Chem., Int. Ed. 2000, 39, 4512 .

(6) (a) Giije, J. W.; Roesky, H. W. Chem. Rev. 1994, 94, 895. (b) Bryndza, H. E.; Tam, W. Chem. Rev. 1988, 88, 1163.

(7) Fandos, R.; Hernández, C.; Otero, A.; Rodríguez, A.; Ruiz, M. J. Organometallics 1999, 18, 2718, and references therein.

(8) (a) Mizuno, T.; Alper, H. J. Mol. Catal. A 1997, 121, 119. (b) Mizuno, T.; Alper, H. J. Mol. Catal. A 1997, 123, 21. (c) Grushin, V. V.; Kuznetsov, V. F.; Bensimon, C.; Alper, H. Organometallics 1995, 14, 3927. (d) Brune, H.-A.; Unsin, J.; Hemmer, R.; Reichhardt, M. J. Organomet. Chem. 1989, 369, 335. (e) Brune, H.-A.; Hemmer, R.; Unsin, J.; Holl, K.; Thewalt, U. Z. Naturforsh., B 1988, 43, 487.

(9) (a) Nishimura, T.; Katoh, T.; Hayashi, T. Angew. Chem., Int. Ed. 2007, 46, 4937. (b) Nishimura, T.; Hirabayashi, S.; Yasuhara, Y.; Hayashi, T. J. Am. Chem. Soc. 2006, 128, 2556. (c) Kina, A.; Iwamura, H.; Hayashi, T. J. Am. Chem. Soc. 2006, 128, 3904. (d) Kina, A.; Yasuhara, Y.; Nishimura, T.; Iwamura, H.; Hayashi, T. Chem. Asian J. 2006, 1, 707. (e) Miura, T.; Shimada, M.; Murakami, M. J. Am. Chem. Soc. 2005, 127, 1094. (f) Yoshida, K.; Hayashi, T. J. Am. Chem. Soc. 2003, 125, 2872. (g) Hayashi, T.; Takahashi, M.; Takaya, Y.; Ogasawara, M. J. Am. Chem. Soc. 2002, 124, 5052. (h) Yoshida, K.; Ogasawara, M.; Hayashi, T. J. Am. Chem. Soc. 2002, 124, 10984. (i) Hayashi, T.; Tokunaga, N.; Yoshida, K.; Han, J. W. J. Am. Chem. Soc. 2002, 124, 12102.

(10) (a) Zhao, P.; Incarvito, C. D.; Hartwig, J. F. J. Am. Chem. Soc. 2007, 129, 1876. (b) Krug, C.; Hartwig, J. F. Organometallics 2004, 23, 4594 .

(11) (a) Gevert, O.; Wolf, J.; Werner, H. Organometallics 1996, 15, 2806. (b) Herrmann, W. A.; Kulpe, J. A.; Konkol, W.; Bahrmann, H. J. Organomet. Chem. 1990, 389, 85.

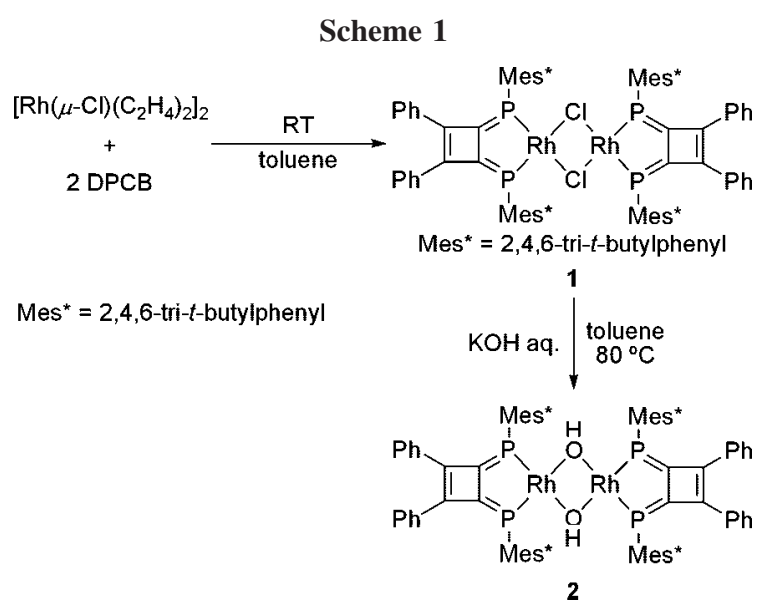

$\left(\mathrm{Rh}-\mathrm{O}=2.077(3), \mathrm{Rh}-\mathrm{O}^{*}=2.082(3) \AA\right)$ distances are comparable to those of phosphane analogues $(\mathrm{Rh}-\mathrm{P}=$ $2.185-2.241 \AA, \mathrm{Rh}-\mathrm{O}=2.064-2.127 \AA)^{8 \mathrm{e}, 11 \mathrm{a}}$ The interatomic distance of $\mathrm{Rh} \cdots \mathrm{Rh}^{*}$ is $3.273 \AA$, showing the absence of bonding interaction.

Reaction of 2 with $\mathrm{HSiMe}_{2} \mathrm{Ph}$. We have recently found that the ruthenium chloride $\left[\mathrm{Ru}_{2} \mathrm{Cl}_{2}(\mu-\mathrm{Cl})_{2}(\mathrm{CO})_{2}(\mathrm{DPCB}-\mathrm{OMe})_{2}\right]$ is cleanly reduced to hydride by the treatment with $\mathrm{HSiMe}_{2} \mathrm{Ph}$ and water, where an $\mathrm{Ru}-\mathrm{OH}$ species undergoes metathesis with $\mathrm{HSiMe}_{2} \mathrm{Ph}$ to give an $\mathrm{Ru}-\mathrm{H}$ species and $\mathrm{HOSiMe}_{2} \mathrm{Ph}^{5}{ }^{5 \mathrm{a}}$ Thus, the reaction of 2 with $\mathrm{HSiMe}_{2} \mathrm{Ph}$ was examined as the first attempt to synthesize hydridorhodium complexes (eq 1). Complex 2 was treated with excess $\mathrm{HSiMe}_{2} \mathrm{Ph}$ ( 3 equiv/Rh) in THF at room temperature for $27 \mathrm{~h}$. After removal of volatiles, the residue was washed with pentane and dried under vacuum, giving a dark red powder of $\left[\mathrm{Rh}_{2}(\mu-\mathrm{H})(\mu-\mathrm{OH})(\mathrm{DPCB})_{2}\right](3)$ in $84 \%$ yield.

$\mathrm{X}$-ray diffraction analysis of $\mathbf{3}$ revealed the dirhodium structure bearing $\mu-\mathrm{H}$ and $\mu-\mathrm{OH}$ ligands (Figure 2). The rhodium atoms adopt slightly distorted square-planar configurations and

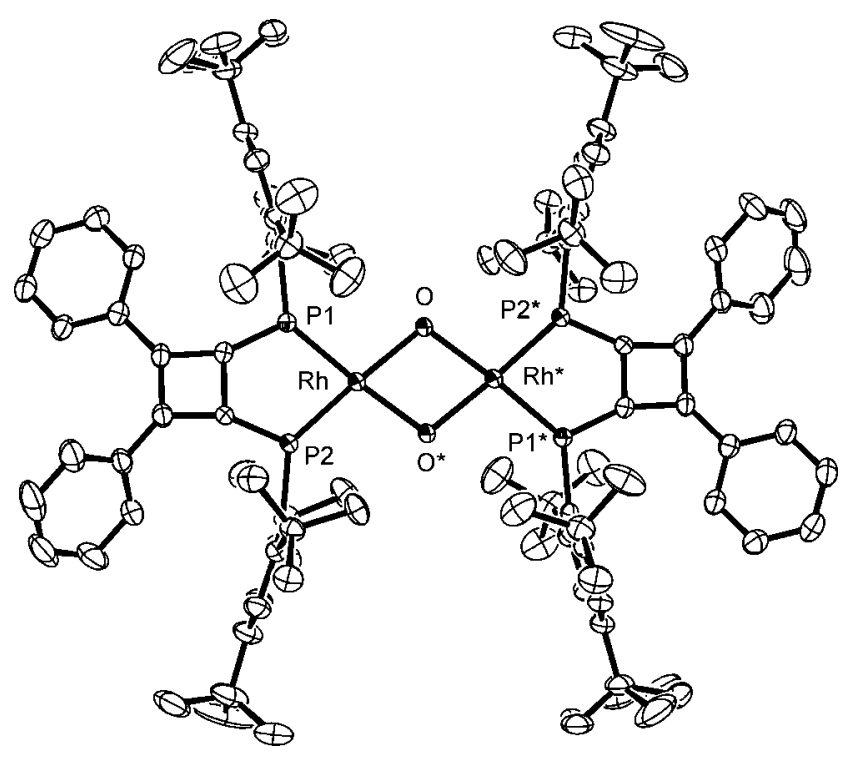

Figure 1. ORTEP drawing of $\mathbf{2} \cdot 2\left(\mathrm{C}_{5} \mathrm{H}_{12}\right)$ with thermal ellipsoids at the $50 \%$ probability level. Hydrogen atoms and pentane molecules are omitted for clarity. Selected bond distances $(\AA)$ and angles (deg): $\mathrm{Rh}-\mathrm{P} 1=2.1879(12), \mathrm{Rh}-\mathrm{P} 2=2.1863(12), \mathrm{Rh}-\mathrm{O}=2.077(3)$, $\mathrm{Rh}-\mathrm{O}^{*}=2.082(3), \mathrm{P} 1-\mathrm{Rh}-\mathrm{P} 2=82.59(4), \mathrm{O}-\mathrm{Rh}-\mathrm{O}^{*}=$ 76.19(12), $\mathrm{P} 1-\mathrm{Rh}-\mathrm{O}=100.24(8), \mathrm{P} 2-\mathrm{Rh}-\mathrm{O}^{*}=100.92(8)$. Asterisks indicate atoms generated by the symmetric operation $(-x$, $-y,-z)$. 




Figure 2. ORTEP drawing of $\mathbf{3} \cdot \mathrm{Et}_{2} \mathrm{O}$ with thermal ellipsoids at the $50 \%$ probability level. Hydrogen atoms except for the $\mu-\mathrm{H}$

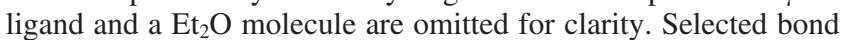
distances $(\AA)$ and angles (deg): Rh1-Rh2 = 2.7486(12), Rh1-P1 $=2.1660(19), \mathrm{Rh} 1-\mathrm{P} 2=2.2178(19), \mathrm{Rh} 2-\mathrm{P} 3=2.174(2)$, $\mathrm{Rh} 2-\mathrm{P} 4=2.202(2), \mathrm{Rh} 1-\mathrm{H}=1.87(5), \mathrm{Rh} 2-\mathrm{H}=1.90(5)$, $\mathrm{Rh} 1-\mathrm{O}=2.087(4), \mathrm{Rh} 2-\mathrm{O}=2.098(4), \mathrm{P} 1-\mathrm{Rh} 1-\mathrm{P} 2=83.79(7)$, $\mathrm{P} 3-\mathrm{Rh} 2-\mathrm{P} 4=83.36(7), \mathrm{Rh} 1-\mathrm{O}-\mathrm{Rh} 2=82.11(16)$. Dihedral angel (deg): $\mathbf{A}-\mathbf{B}=23.2(2)$.

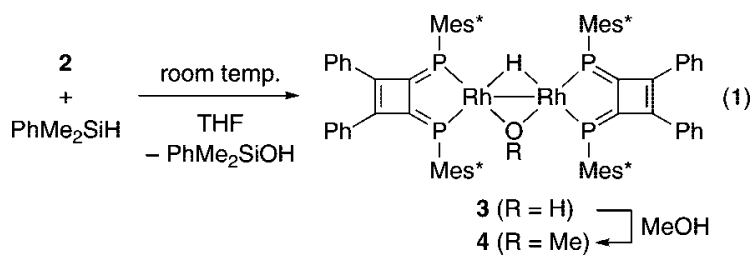

are connected with each other by a metal-metal bond (2.7486(12) $\AA)$. Reflecting the higher trans influence of hydrido ligand than hydroxo ligand, the Rh1-P2 (2.2178(19) $\AA$ ) and Rh2-P4 (2.202(2) $\AA$ ) bonds are clearly longer than the Rh1-P1

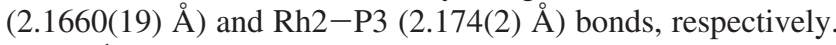

The ${ }^{1} \mathrm{H}$ NMR signal of the $\mu$-hydrido ligand appeared at $\delta$ -9.34 as a triplet of triplets of triplets, due to the couplings with ${ }^{31} \mathrm{P}$ nuclei at the trans and cis positions $\left({ }^{2} J_{\mathrm{PH}}=85,28 \mathrm{~Hz}\right)$ and with ${ }^{103} \mathrm{Rh}$ nuclei $\left({ }^{1} J_{\mathrm{RhH}}=15 \mathrm{~Hz}\right)$, showing the occurrence of a tight connection among the $\mu$-hydrido ligand and rhodium centers. On the other hand, the ${ }^{31} \mathrm{P}\left\{{ }^{1} \mathrm{H}\right\} \mathrm{NMR}$ signal at $\delta 156.1$ $\left(\mathrm{d},{ }^{1} J_{\mathrm{RhP}}=244 \mathrm{~Hz}\right)$ assignable to the phosphorus trans to the $\mu$-OH ligand was significantly broadened, while the other at $\delta$ $175.6\left(\mathrm{dd},{ }^{1} J_{\mathrm{RhP}}=208 \mathrm{~Hz},{ }^{1} J_{\mathrm{PP}}=12 \mathrm{~Hz}\right)$ remained as a sharp signal. Since the $\mathrm{OH}$ proton signal was broadened as well, it is likely that complex 3 undergoes a rapid exchange of the $\mu-\mathrm{OH}$ ligand with residual water in solution, probably via the process given in eq 2 . Actually, the $\mu-\mathrm{OH}$ ligand in $\mathbf{3}$ was readily replaced by $\mathrm{MeOH}$ to give 4 , having a $\mu$-OMe ligand, in $67 \%$ yield after isolation as dark brown crystals (eq 1).

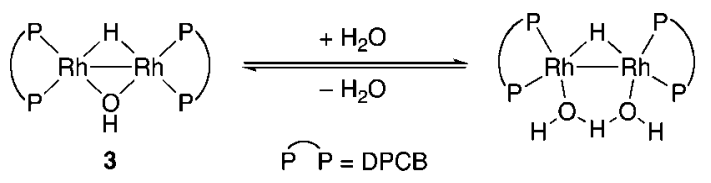

As seen from the ORTEP drawing given in Figure 3, complex $\mathbf{4}$ has a structure very similar to $\mathbf{3}$, while the $\mathrm{Rh}-\mathrm{Rh}$ bond

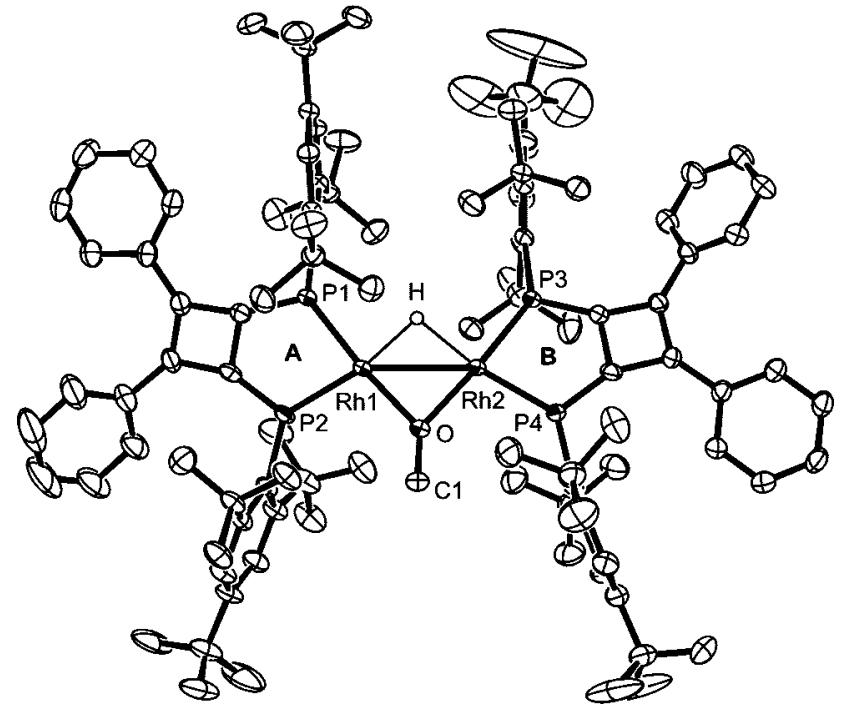

Figure 3. ORTEP drawing of $\mathbf{4}$ with thermal ellipsoids at the $50 \%$ probability level. Hydrogen atoms expect for the $\mu$-H ligand are omitted for clarity. Selected bond distances $(\AA)$ and angles (deg): $\mathrm{Rh} 1-\mathrm{Rh} 2=2.7682(5), \mathrm{Rh} 1-\mathrm{P} 1=2.1705(9), \mathrm{Rh} 1-\mathrm{P} 2=2.2229(9)$, $\mathrm{Rh} 2-\mathrm{P} 3=2.1769(9), \mathrm{Rh} 2-\mathrm{P} 4=2.2177(10), \mathrm{Rh} 1-\mathrm{H}=1.79(4)$, $\mathrm{Rh} 2-\mathrm{H}=1.88(4), \mathrm{Rh} 1-\mathrm{O}=2.022(3), \mathrm{Rh} 2-\mathrm{O}=2.017(3), \mathrm{O}-\mathrm{C} 1$ $=1.397(5), \mathrm{P} 1-\mathrm{Rh} 1-\mathrm{P} 2=83.18(4), \mathrm{P} 3-\mathrm{Rh} 2-\mathrm{P} 4=83.08(4)$, $\mathrm{Rh} 1-\mathrm{O}-\mathrm{Rh} 2=86.52(10), \mathrm{Rh} 1-\mathrm{O}-\mathrm{C} 1=129.5(2), \mathrm{Rh} 2-\mathrm{O}-\mathrm{C} 1$ $=133.8(3), \mathbf{A}-\mathbf{B}=10.0(1)$.

Scheme 2
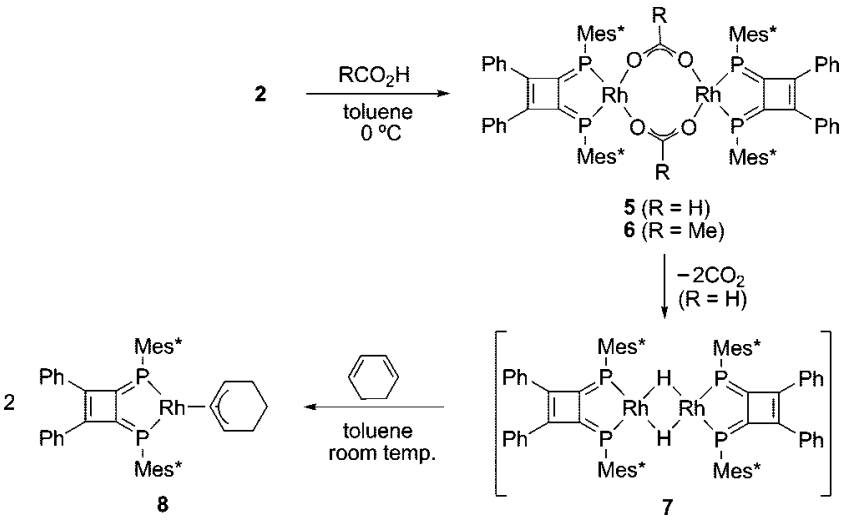

$(2.7682(5) \AA)$ is somewhat longer, and the $\mathrm{Rh}-\mathrm{O}$ bonds (2.022(3), 2.017(3) ^) are clearly shorter than 3 .

Reaction of 2 with $\mathbf{H C O}_{2} \mathbf{H}$. The reaction of $\mathbf{2}$ with $\mathrm{HSiMe}_{2} \mathrm{Ph}$ formed mono- $\mu$-hydrido complex $\mathbf{3}$ exclusively, and no further reduction took place even in the presence of a large excess of $\mathrm{HSiMe}_{2} \mathrm{Ph}$ ( $>20$ equiv/Rh). Since stronger reducing agents such as $\mathrm{NaBH}_{4}$ and EtLi provided complex mixtures, we next examined the reaction with formic acid to synthesize di- $\mu$-hydrido complex 7 (Scheme 2).

When 2 was treated with $\mathrm{HCO}_{2} \mathrm{H}\left(1\right.$ equiv/Rh) at $0{ }^{\circ} \mathrm{C}$ in toluene, the ${ }^{31} \mathrm{P}\left\{{ }^{1} \mathrm{H}\right\} \mathrm{NMR}$ signal at $\delta 164.1\left(\mathrm{~d},{ }^{1} J_{\mathrm{RhP}}=244\right.$ $\mathrm{Hz}$ ) instantly disappeared, and a new broad signal, assignable to di- $\mu$-formato complex 5, appeared at $\delta 163.2\left(\mathrm{~d},{ }^{1} J_{\mathrm{RhP}}=262\right.$ $\mathrm{Hz}$ ). Although this complex was too unstable to be isolated, the related di- $\mu$-acetato complex 6 could be obtained in $98 \%$ yield, using $\mathrm{MeCO}_{2} \mathrm{H}$ instead of $\mathrm{HCO}_{2} \mathrm{H}$. The ${ }^{1} \mathrm{H}$ NMR data of both complexes were almost identical to each other, except for the signals of bridging ligands. Complex 5 readily decomposed with liberation of $\mathrm{CO}_{2}$ at room temperature. In the presence of 1,3-cyclohexadiene, $\eta^{3}$-cyclohexenyl complex 8 was formed, as confirmed by NMR spectroscopy. This observation is 


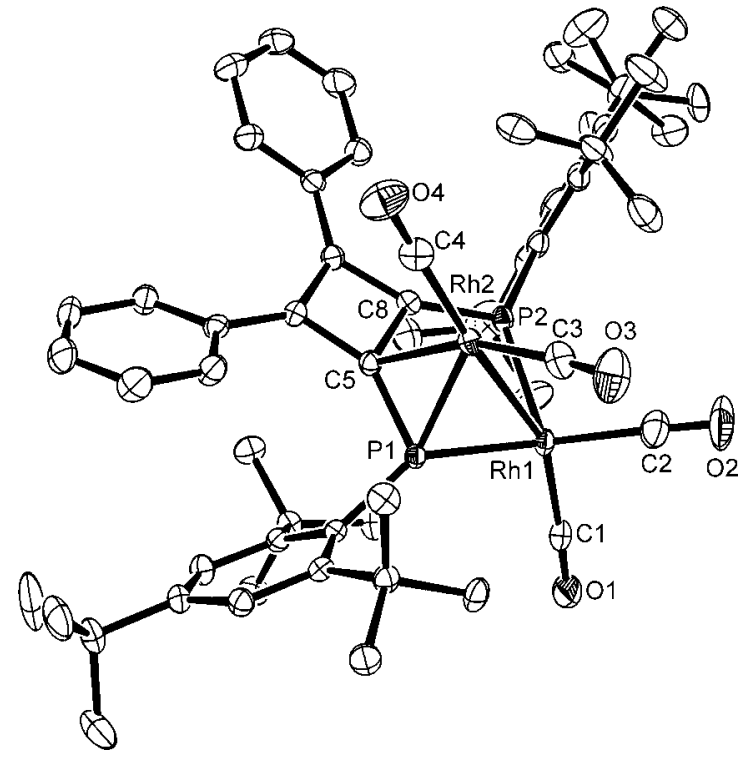

Figure 4. ORTEP drawing of $9 \cdot \mathrm{C}_{5} \mathrm{H}_{12}$ with thermal ellipsoids at the $50 \%$ probability level. Hydrogen atoms and a pentane molecule are omitted for clarity. Selected bond distances $(\AA)$ and angles (deg): $\mathrm{Rh} 1-\mathrm{Rh} 2=2.7452(6), \mathrm{Rh} 1-\mathrm{P} 1=2.2592(8), \mathrm{Rh} 1-\mathrm{P} 2=2.4180(9)$, $\mathrm{Rh} 2-\mathrm{P} 1=2.3909(8), \mathrm{Rh} 1-\mathrm{C} 1=1.881(3), \mathrm{Rh} 1-\mathrm{C} 2=1.905(3)$, $\mathrm{Rh} 2-\mathrm{C} 3=1.877(3), \mathrm{Rh} 2-\mathrm{C} 4=1.912(3), \mathrm{Rh} 2-\mathrm{C} 5=2.203(2)$, $\mathrm{P} 1-\mathrm{C} 5=1.743(2), \mathrm{P} 2-\mathrm{C} 8=1.696(2), \mathrm{P} 1-\mathrm{Rh} 1-\mathrm{P} 2=85.84(2)$, $\mathrm{C} 1-\mathrm{Rh} 1-\mathrm{C} 2=95.00(11), \mathrm{P} 1-\mathrm{Rh} 1-\mathrm{C} 1=101.84(7), \mathrm{P} 2-\mathrm{Rh} 1-\mathrm{C} 2$ $=106.36(9), \mathrm{Rh} 1-\mathrm{Rh} 2-\mathrm{C} 5=80.45(6), \mathrm{C} 3-\mathrm{Rh} 2-\mathrm{C} 4=97.10(11)$, $\mathrm{Rh} 1-\mathrm{Rh} 2-\mathrm{C} 3=87.93(8), \mathrm{C} 4-\mathrm{Rh} 2-\mathrm{C} 5=96.53(10), \mathrm{Rh} 1-\mathrm{Rh} 2-\mathrm{P} 1$ $=51.63(2), \mathrm{P} 1-\mathrm{Rh} 2-\mathrm{C} 5=44.37(6)$.

consistent with the formation of $\left[\mathrm{Rh}_{2}(\mu-\mathrm{H})_{2}(\mathrm{DPCB})_{2}\right](7)$, which undergoes the insertion of 1,3-cyclohexadiene to give $\mathbf{8}$.

Reaction of 2 with CO. Next, complex 2 was treated with $\mathrm{CO}$. It has been documented that hydroxycarbonyl complexes formed by the insertion of $\mathrm{CO}$ into a $\mathrm{Rh}-\mathrm{OH}$ bond undergo decarboxylation to give hydrido complexes. ${ }^{12}$ However, the reaction of $\mathbf{2}$ with $\mathrm{CO}$ in pentane afforded the novel dirhodium complex $\left[\mathrm{Rh}_{2}(\mu-\kappa P, P ; \kappa P, C\right.$-DPCB $\left.)(\mathrm{CO})_{4}\right]$ (9) instead, along with dissociation of one of the DPCB ligands (eq 3). Slow evaporation of the solvent under the flow of $\mathrm{CO}$ gas provided dark brown crystals with the composition $\mathbf{9} \cdot \mathrm{C}_{5} \mathrm{H}_{12}$ in $55 \%$ yield, suitable for X-ray diffraction analysis.

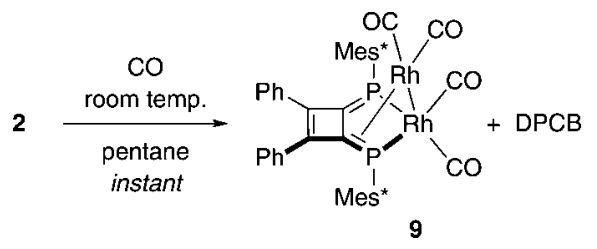

Figure 4 shows the X-ray crystal structure. There are two nonequivalent rhodium centers, connected by a metal-metal bond $(2.7452(6) \AA)$. One (Rh1) adopts a significantly distorted five-coordinate structure having $\mathrm{P} 1, \mathrm{P} 2, \mathrm{C} 1, \mathrm{C} 2$, and $\mathrm{Rh} 2$ as coordination atoms. On the other hand, the other rhodium atom $(\mathrm{Rh} 2)$ is combined with the Rh1-P1-C5 moiety in $\eta^{3}$-fashion. ${ }^{13}$ Thus, the partial structure around $\mathrm{Rh} 2$ may be regarded as a

(12) (a) Johansson, R.; Wendt, O. F. Organometallics 2007, 26, 2426. (b) Torresan, I.; Michelin, R. A.; Marsella, A.; Zanardo, A.; Pinna, F.; Strukul, G. Organometallics 1991, 10, 623. (c) Bennett, M. A. J. Mol. Catal. 1987, 41,1 .

(13) A similar coordination mode of DPCB has been reported for a tungsten complex: Yoshifuji, M.; Ichikawa, Y.; Yamada, N.; Toyota, K. Chem. Commun. 1998, 27.

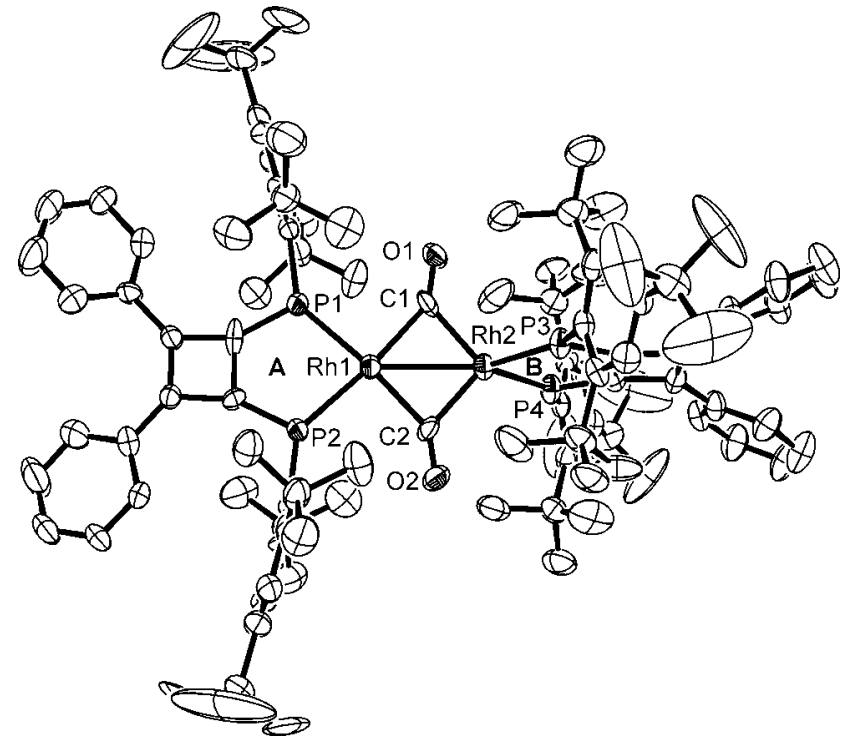

Figure 5. ORTEP drawing of $\mathbf{1 0}$ with thermal ellipsoids at the $50 \%$ probability level. Hydrogen atoms are omitted for clarity. Selected bond distances $(\AA)$ and angles $(\mathrm{deg})$ : Rh1-Rh2 = 2.6802(11), $\mathrm{Rh} 1-\mathrm{P} 1=2.282(2), \mathrm{Rh} 1-\mathrm{P} 2=2.279(2), \mathrm{Rh} 1-\mathrm{C} 1=2.008(8)$, $\mathrm{Rh} 1-\mathrm{C} 2=2.028(8), \mathrm{Rh} 2-\mathrm{P} 3=2.329(2), \mathrm{Rh} 2-\mathrm{P} 4=2.325(2)$, $\mathrm{Rh} 2-\mathrm{C} 1=1.975(9), \mathrm{Rh} 2-\mathrm{C} 2=1.986(10), \mathrm{C} 1-\mathrm{O} 1=1.179(10)$, $\mathrm{C} 2-\mathrm{O} 2=1.167(10), \mathrm{P} 1-\mathrm{Rh} 1-\mathrm{P} 2=82.93(8), \mathrm{C} 1-\mathrm{Rh} 1-\mathrm{C} 2=$ 94.6(4), $\mathrm{P} 3-\mathrm{Rh} 2-\mathrm{P} 4=85.78(8), \mathrm{C} 1-\mathrm{Rh} 2-\mathrm{C} 2=97.0(3)$, $\mathrm{Rh} 1-\mathrm{C} 1-\mathrm{O} 1=145.8(7), \mathrm{Rh} 2-\mathrm{C} 1-\mathrm{O} 1=129.4(7), \mathrm{Rh} 1-\mathrm{C} 2-\mathrm{O} 2$ $=145.7(7), \mathrm{Rh} 2-\mathrm{C} 2-\mathrm{O} 2=130.2(7), \mathbf{A}-\mathbf{B}=80.6(4)$.

$\pi$-allyl complex bearing two carbonyl ligands. The $\mathrm{C} 3-\mathrm{Rh} 2-\mathrm{C} 4$ angle $\left(97.10(11)^{\circ}\right)$ is within the range of $\pi$-allyl complexes having a $\mathrm{d}^{8}$ metal center.

Unlike the crystal structure, two phosphorus nuclei of the DPCB ligand were observed equivalently at $\delta 152.9\left(\mathrm{dd},{ }^{1} J_{\mathrm{RhP}}\right.$ $=151,44 \mathrm{~Hz}$ ) in toluene at room temperature, showing the occurrence of a rapid migration of the $\mathrm{Rh}(\mathrm{CO})_{2}$ moiety between the $\mathrm{P}=\mathrm{C}$ bonds (eq 4). The fractional behavior did not freeze even at $-90{ }^{\circ} \mathrm{C}$.

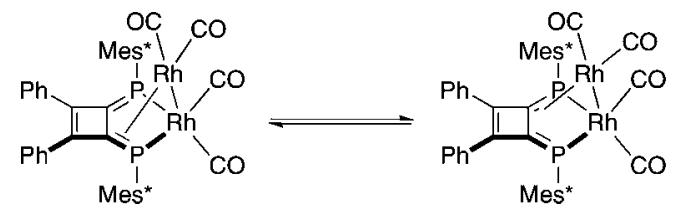

Complex 9 is stable in solution under a $\mathrm{CO}$ atmosphere even in the presence of free DPCB, but readily converted to $\left[\mathrm{Rh}_{2}(\mu\right.$ $\left.\mathrm{CO})_{2}(\mathrm{DPCB})_{2}\right](\mathbf{1 0})$ when the $\mathrm{CO}$ gas was purged from the solution (eq 5). The IR and NMR data were consistent with the dirhodium structure having two $\mu$-CO ligands. A strong $v_{\mathrm{CO}}$ absorption band appeared in a typical region of bridging carbonyls $\left(1766 \mathrm{~cm}^{-1}\right)$. The ${ }^{13} \mathrm{C}\left\{{ }^{1} \mathrm{H}\right\}$ NMR signal of $\mu$-CO ligands ( $\delta$ 172.1) was observed as a triplet due to the coupling with two ${ }^{103} \mathrm{Rh}$ nuclei $\left({ }^{1} J_{\mathrm{RhC}}=28 \mathrm{~Hz}\right)$.

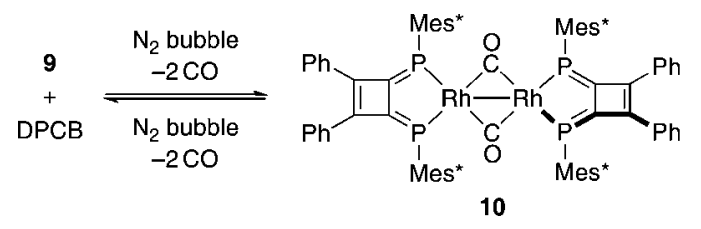

Figure 5 shows the X-ray structure of $\mathbf{1 0}$. Although the quality of diffraction data was low $\left(R_{1}=0.170\right)$, an interesting structural 
Scheme 3<smiles>O=C1N(I)C(=O)C1(Cl)Cl</smiles><smiles>O=C1N(I)C2(I)C(=O)N(I)C1(I)C2(I)I</smiles><smiles>O=C1N(I)C(=O)C1(I)I(I)I</smiles>

feature emerged. ${ }^{14}$ Complex $\mathbf{1 0}$ is a 30 -electron dimer having a rhodium-rhodium bond $(2.6802(11) \AA)$. The Rh1 center has a square-planar geometry, ${ }^{15 a}$ whereas the Rh2 atom is in a distorted tetrahedral configuration. ${ }^{15 b}$ Two Rh(DPCB) units are oriented orthogonal to each other with the dihedral angle of $80.6(4)^{\circ}$. Reflecting the highly unsymmetrical dirhodium framework, both $\mu$-CO ligands are tilted toward the Rh2 atom by 8.2 $(\mathrm{C} 1-\mathrm{O} 1)$ and $7.8^{\circ}(\mathrm{C} 2-\mathrm{O} 2)$, respectively. Furthermore, the Rh2-C1 and Rh2-C2 bonds (1.975(9), 1.986(10) $\AA$ ) are shorter than the Rh1-C1 and Rh1-C2 bonds (2.008(8), 2.028(8) $\AA$ ), respectively.

The crystal structures of $\left[\mathrm{L}_{2} \mathrm{M}(\mu-\mathrm{CO})_{2} \mathrm{ML}_{2}^{\prime}\right]$ type complexes have been rationalized by Cotton (Scheme 3). ${ }^{16,17}$ When two metal centers bear the same or very similar ancillary ligands ( $\mathrm{L}$ $=L^{\prime}$ ), they form symmetrical structures of type I or II. On the other hand, when the ancillary ligands with significantly different electronic properties are bound to each metal ( $\mathrm{L} \neq \mathrm{L}^{\prime}$; typically those in donor and acceptor relations), the complexes adopt unsymmetrical structures of type III, involving square-planar and tetrahedral geometries of metal centers and asymmetric bridging of CO ligands. In this context, the X-ray structure of $\mathbf{1 0}$ is quite unique, being categorized into type III despite the coordination of the same DPCB ligands to both rhodium atoms.

The highly distorted coordination structure of $\mathbf{1 0}$ should be attributed principally to steric repulsion between DPCB ligands. The orthogonal arrangement of Rh(DPCB) units most effectively relieves the steric congestion. In this case, the nonequivalent rhodium centers with square-planar and tetrahedral configurations must bear electronic conditions quite distinct from each other. Actually, DFT calculations suggested that the Rh1 atom is much more negatively charged than the Rh2 atom, ${ }^{18}$ and this is an important reason that the complexes of type III commonly have ancillary ligands with significantly different properties at each metal center. As described in the introductory part, DPCB serves not only as a strong $\pi$-acceptor but also as an effective $\sigma$-donor toward transition metals. Therefore, it is likely that this

(14) The poor $R_{1}$ value is mainly due to insufficient disorder treatment for tert-butyl groups. Based on the standard deviations, it has been concluded that the structural data on the $\mathrm{P}_{2} \mathrm{Rh}(\mathrm{CO})_{2} \mathrm{RhP}_{2}$ core deserve discussion.

(15) (a) The sum of the four angles around Rh1: $360.2^{\circ}$. (b) The sum of the four angles around Rh2: 405.2 .

(16) (a) Cotton, F. A. Prog. Inorg. Chem. 1976, 21, 1. (b) Colton, R. McCormick, M. J. Coord. Chem. Rev. 1980, 31, 1.

(17) For examples of di- $\mu$-carbonyl-dirhodium complexes, see: (a) Singh P.; Dammann, C. B.; Hodgson, D. J. Inorg. Chem. 1973, 12, 1335. (b) Burch, R. R.; Muetterties, E. L.; Schultz, A. J.; Gebert, E. G.; Williams, J. M. J. Am. Chem. Soc. 1981, 103, 5517. (c) James, B. R.; Mahajan, D. Rettig, S. J.; Williams, G. M. Organometallics 1983, 2, 1452. (d) Freeman, M. A.; Young, D. A. Inorg. Chgem. 1986, 25, 1556. (e) Shulman, P. M.; Burkhardt, E. D.; Lundquist, E. G.; Pilato, R. S.; Geoffroy, G. L. Organometallics 1987, 6, 101. (f) Cecconi, F.; Chilardi, C. A.; Midollini, S.; Orlandini, A.; Zanello, P.; Heaton, B. T.; Huang, L.; Iggo, J. A.; Bordoni, S. J. Organomet. Chem. 1988, 353, C5. (g) Douglas, S.; Lowe, J. P.; Mahon, M. F.; Warren, J. E.; Whittlesey, M. K. J. Organomet. Chem. 2005, 690, 5027.

(18) DFT calculations for $[\mathrm{Rh}(\mu-\mathrm{CO})(\mathrm{DPCB})]_{2}$ were carried out with the Gaussian 98 program (Revision A.9, Gaussian, Inc., 1998) using B3LYP in conjunction with the standard LanL2DZ basis set and effective core potentials for $\mathrm{Rh}$ and 6-31G(d) basis set for other atoms. This examination showed the Mulliken atomic charges of Rh1 $(-0.14)$ and $\mathrm{Rh} 2(+0.38)$. highly flexible ligand property of DPCB compensates for the imbalance of charge distribution between rhodium atoms, leading to the unusual structural feature of $\mathbf{1 0}$.

\section{Conclusion}

It has been found that the di- $\mu$-hydroxo-dirhodium complex bearing DPCB ligands (2) serves as a versatile starting material for organorhodium complexes. Complex $\mathbf{2}$ is stable in air, but sufficiently reactive toward a variety of substrates including $\mathrm{HSiMe}_{2} \mathrm{Ph}$ and $\mathrm{CO}$, affording complexes with unique structural features. The carbonyl complexes $\mathbf{9}$ and $\mathbf{1 0}$ are of particular interest. DPCB undergoes the $\mu-\kappa P, P ; \kappa P, C$-coordination with two rhodium atoms in 9 and forms a novel $\mathrm{Rh}_{2}(\mu-\mathrm{CO})_{2}$ framework with square-planar and tetrahedral rhodium centers in 10. Both structures demonstrate highly flexible electronic ligand properties of DPCB.

\section{Experimental Section}

General Considerations. All manipulations were carried out under a dry nitrogen atmosphere using standard Schlenk techniques. Toluene and pentane were distilled from sodium benzophenone ketyl. Chloroform- $d$ was purified by passing successively through alumina and activated MS4A columns and degassed by freezepump -thaw cycles prior to use. Benzene- $d_{6}$ and dichloromethane$d_{2}$ were dried over $\mathrm{LiAlH}_{4}$ and $\mathrm{CaH}_{2}$, respectively, and stored over activated MS4A. Dehydrated diethyl ether, tetrahydrofuran, and dichloromethane were obtained from commercial sources. The compounds $\left[\mathrm{Rh}_{2}(\mu-\mathrm{Cl})_{2}\left(\mathrm{C}_{2} \mathrm{H}_{4}\right)_{4}\right]^{19}$ and $\mathrm{DPCB}^{3}$ were synthesized by the literature methods. Other chemicals were purchased and used as received.

NMR spectra were recorded on a Bruker Avance 400 spectrometer at $20^{\circ} \mathrm{C}$ unless otherwise noted. Chemical shifts are reported in $\delta$, referenced to ${ }^{1} \mathrm{H}$ (of residual protons) and ${ }^{13} \mathrm{C}$ signals of deuterated solvents as internal standard or to the ${ }^{31} \mathrm{P}$ signal of $85 \%$ $\mathrm{H}_{3} \mathrm{PO}_{4}$ as an external standard. IR spectra were recorded on a JASCO FT/IR-410 instrument. Elemental analysis was performed by the ICR Analytical Laboratory, Kyoto University.

Preparation of $\left[\mathrm{Rh}_{2}(\mu-\mathrm{Cl})_{2}(\mathrm{DPCB})_{2}\right]$ (1). To a solution of DPCB $(827.0 \mathrm{mg}, 1.095 \mathrm{mmol})$ in toluene $(10 \mathrm{~mL})$ was added $\left[\mathrm{Rh}_{2}(\mu-\mathrm{Cl})_{2}\left(\mathrm{C}_{2} \mathrm{H}_{4}\right)_{4}\right](216.4 \mathrm{mg}, 0.556 \mathrm{mmol})$ at room temperature. The color of the solution immediately turned from yellow to dark brown. After $1 \mathrm{~h}$, insoluble materials were removed by filtration through a Celite pad, and volatiles were removed under reduced pressure. The residue was washed with diethyl ether at $0{ }^{\circ} \mathrm{C}$ and dried under vacuum, giving a dark brown microcrystalline powder of 1 (878.7 mg, 90\%). Mp: $225{ }^{\circ} \mathrm{C}(\mathrm{dec}) .{ }^{1} \mathrm{H} \mathrm{NMR}\left(\mathrm{CDCl}_{3}\right): \delta$ $1.40(\mathrm{~s}, 36 \mathrm{H}, p-t \mathrm{Bu}), 1.76(\mathrm{~s}, 72 \mathrm{H}, o-t \mathrm{Bu}), 6.63(\mathrm{~d}, J=7.7 \mathrm{~Hz}$, $8 \mathrm{H}, o-\mathrm{Ph}), 6.79(\mathrm{t}, J=7.8 \mathrm{~Hz}, 8 \mathrm{H}, m-\mathrm{Ph}), 7.02(\mathrm{t}, J=7.4 \mathrm{~Hz}, 4 \mathrm{H}$, $p$-Ph), 7.46 (s, 8H, $m$-PAr). ${ }^{13} \mathrm{C}\left\{{ }^{1} \mathrm{H}\right\} \mathrm{NMR}\left(\mathrm{CDCl}_{3}\right): \delta 31.5,34.6$, 35.3, 39.1, 122.7, 126.5, 127.2, 128.0, 128.1 (d, $J=7.5 \mathrm{~Hz}), 132.9$, $142.1(\mathrm{~m}, J=62,33 \mathrm{~Hz}), 152.0,156.4,157.9(\mathrm{dd}, J=88,10 \mathrm{~Hz})$. ${ }^{31} \mathrm{P}\left\{{ }^{1} \mathrm{H}\right\}$ NMR $\left(\mathrm{CDCl}_{3}\right): \delta 160.6(\mathrm{~d}, J=250 \mathrm{~Hz})$. Anal. Calcd for $\mathrm{C}_{104} \mathrm{H}_{136} \mathrm{Cl}_{2} \mathrm{P}_{4} \mathrm{Rh}_{2}$ : C, 69.91; H, 7.67. Found: 69.97; H, 7.84.

Preparation of $\left[\mathrm{Rh}_{2}(\boldsymbol{\mu}-\mathrm{OH})_{2}(\mathrm{DPCB})_{2}\right]$ (2). To a dark brown solution of 1 (372.2 $\mathrm{mg}, 0.208 \mathrm{mmol})$ in toluene $(15 \mathrm{~mL})$ was added an aqueous solution $(9 \mathrm{~mL})$ of $\mathrm{KOH}(2.5 \mathrm{~g}, 44.6 \mathrm{mmol})$ at room temperature. The resulting mixture was stirred at $80^{\circ} \mathrm{C}$ for $10 \mathrm{~h}$. The dark yellow organic layer was separated, washed with $\mathrm{H}_{2} \mathrm{O}$, and transferred to another Schlenk tube through a cotton-tipped cannula. After volatiles were removed under reduced pressure, the residue was washed with pentane at $0{ }^{\circ} \mathrm{C}$ and dried under vacuum to give an analytically pure sample of $\mathbf{2}$ as a dark yellow microcrystalline powder $(266.8 \mathrm{mg}, 73 \%)$. Evaporation of the 
Table 1. Details of the X-ray Structure Determinations of $2 \cdot 2\left(\mathrm{C}_{5} \mathrm{H}_{12}\right), 3 \cdot \mathrm{Et}_{2} \mathrm{O}, 4,9 \cdot \mathrm{C}_{5} \mathrm{H}_{12}$, and 10

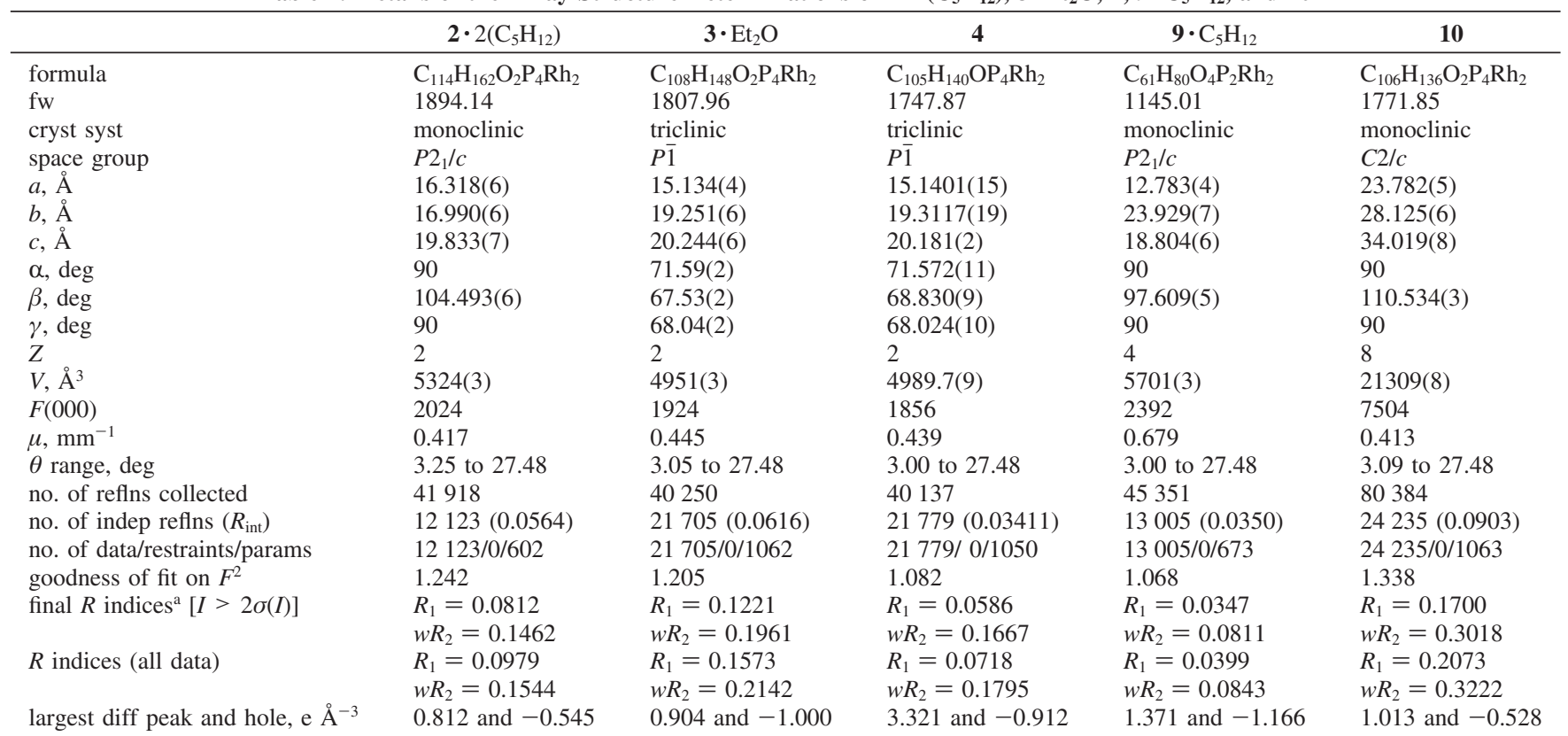

pentane washings gave additional product of $2(89.3 \mathrm{mg}, 25 \%$; totally $98 \%)$. Mp: $140{ }^{\circ} \mathrm{C}(\mathrm{dec}) .{ }^{1} \mathrm{H}$ NMR $\left(\mathrm{C}_{6} \mathrm{D}_{6}\right): \delta-1.66(\mathrm{~s}, 2 \mathrm{H}$, $\mu-\mathrm{OH}), 1.23$ (s, 36H, $p$ - $t \mathrm{Bu}), 2.00$ (s, 72H, o- $t \mathrm{Bu}), 6.74$ (t, $J=7.4$ $\mathrm{Hz}, 8 \mathrm{H}, m-\mathrm{Ph}), 6.84(\mathrm{t}, J=7.4 \mathrm{~Hz}, 4 \mathrm{H}, p-\mathrm{Ph}), 7.00(\mathrm{~d}, J=7.1$ $\mathrm{Hz}, 8 \mathrm{H}, o-\mathrm{Ph}), 7.44$ (s, 8H, m-PAr). ${ }^{13} \mathrm{C}\left\{{ }^{1} \mathrm{H}\right\} \mathrm{NMR}\left(\mathrm{C}_{6} \mathrm{D}_{6}\right): \delta 31.5$, $34.6,35.2,39.2,122.4,125.6,126.6,127.2,129.3(\mathrm{~d}, J=6 \mathrm{~Hz})$, 134.1, $142.2(\mathrm{~m}), 151.9,156.6,157.6(\mathrm{~m}) .{ }^{31} \mathrm{P}\left\{{ }^{1} \mathrm{H}\right\}$ NMR $\left(\mathrm{C}_{6} \mathrm{D}_{6}\right)$ : $\delta 164.1(\mathrm{~d}, J=244 \mathrm{~Hz})$. Anal. Calcd for $\mathrm{C}_{104} \mathrm{H}_{138} \mathrm{O}_{2} \mathrm{P}_{4} \mathrm{Rh}_{2}$ : C, 71.38; H, 7.95. Found: C, 70.99; H, 8.22.

Preparation of $\left[\mathrm{Rh}_{2}(\boldsymbol{\mu}-\mathrm{H})(\boldsymbol{\mu}-\mathrm{OH})(\mathrm{DPCB})_{2}\right](3)$. To a solution of 2 (251.8 mg, $0.143 \mathrm{mmol})$ in THF $(8.0 \mathrm{~mL})$ was added $\mathrm{HSiMe}_{2} \mathrm{Ph}(135 \mu \mathrm{L}, 0.881 \mathrm{mmol})$ at room temperature. The solution gradually changed from dark yellow to dark red. After $27 \mathrm{~h}$, volatiles were removed under reduced pressure, and the residue was washed with pentane at $0{ }^{\circ} \mathrm{C}$ and dried under vacuum to give a dark red powder of 3 (208.7 mg, 84\%). Mp: $120{ }^{\circ} \mathrm{C}(\mathrm{dec}) .{ }^{1} \mathrm{H}$ NMR $\left(\mathrm{C}_{6} \mathrm{D}_{6}\right)$ : $\delta-9.34$ (ttt, $J=85,28,15 \mathrm{~Hz}, 1 \mathrm{H}, \mu-\mathrm{H}), 1.42(\mathrm{~s}, 36 \mathrm{H}, p-t \mathrm{Bu})$, $1.83(\mathrm{~s}, 36 \mathrm{H}, o-t \mathrm{Bu}), 1.90(\mathrm{~s}, 36 \mathrm{H}, o-t \mathrm{Bu}), 6.77(\mathrm{t}, J=6.9 \mathrm{~Hz}, 4 \mathrm{H}$, $m-\mathrm{Ph}), 6.80(\mathrm{t}, J=6.6 \mathrm{~Hz}, 4 \mathrm{H}, m-\mathrm{Ph}), 6.88(\mathrm{~m}, 4 \mathrm{H}, p-\mathrm{Ph}), 7.07$ $(\mathrm{d}, J=7.2 \mathrm{~Hz}, 4 \mathrm{H}, o-\mathrm{Ph}), 7.09(\mathrm{~d}, J=7.5 \mathrm{~Hz}, 4 \mathrm{H}, o-\mathrm{Ph}), 7.60(\mathrm{~s}$, 2H, $m$-PAr), 7.61 (s, 2H, m-PAr), 7.65 (s, 4H,m-PAr). ${ }^{13} \mathrm{C}\left\{{ }^{1} \mathrm{H}\right\}$ $\operatorname{NMR}\left(\mathrm{C}_{6} \mathrm{D}_{6}\right): \delta 31.6,31.7,34.0,35.2,35.4,35.5,39.2,39.4,122.4$, $122.8,122.9,126.8,127.4,127.3,128.5,132.2,134.0,134.3,134.4$ $(\mathrm{d}, J=5 \mathrm{~Hz}), 134.5(\mathrm{~d}, J=5 \mathrm{~Hz}), 141.7(\mathrm{dd}, J=56,30 \mathrm{~Hz})$, $144.9(\mathrm{dd}, J=57,29 \mathrm{~Hz}), 151.8,152.2,155.7,156.9,159.0(\mathrm{~m})$, $162.5(\mathrm{~m}) .{ }^{31} \mathrm{P}\left\{{ }^{1} \mathrm{H}\right\}$ NMR $\left(\mathrm{C}_{6} \mathrm{D}_{6}\right): \delta 175.6(\mathrm{dd}, J=208,12 \mathrm{~Hz})$, $156.1(\mathrm{~d}, J=244 \mathrm{~Hz})$. Anal. Calcd for $\mathrm{C}_{104} \mathrm{H}_{138} \mathrm{OP}_{4} \mathrm{Rh}_{2}$ : C, 72.04; H, 8.02. Found: C, 71.74; H, 8.18.

Preparation of $\left[\mathrm{Rh}_{2}(\boldsymbol{\mu}-\mathrm{H})(\boldsymbol{\mu}-\mathrm{OMe})(\mathrm{DPCB})_{2}\right](4)$. A solution of 3 (113.9 mg, $0.0657 \mathrm{mmol})$ in THF $(1.5 \mathrm{~mL})$ was prepared, layered with $\mathrm{MeOH}(6.0 \mathrm{~mL})$, and allowed to stand at room temperature for 2 days to give dark brown crystals of 4 (96.1 mg, 67\%). ${ }^{1} \mathrm{H}$ NMR $\left(\mathrm{C}_{6} \mathrm{D}_{6}\right): \delta-9.80$ (ttt, $\left.J=84,26,15 \mathrm{~Hz}, 1 \mathrm{H}, \mu-\mathrm{H}\right), 1.37$ (s, $18 \mathrm{H}, p-t \mathrm{Bu}), 1,41(\mathrm{~s}, 18 \mathrm{H}, p-t \mathrm{Bu}), 1.81(\mathrm{~s}, 36 \mathrm{H}, o-t \mathrm{Bu}), 1.92$ (s, $36 \mathrm{H}, o-t \mathrm{Bu}), 3.88(\mathrm{~s}, 3 \mathrm{H}, \mathrm{OMe}), 6.77(\mathrm{t}, J=7.2 \mathrm{~Hz}, 4 \mathrm{H}, m-\mathrm{Ph})$, $6.79(\mathrm{t}, J=7.5 \mathrm{~Hz}, 4 \mathrm{H}, m-\mathrm{Ph}), 6.87(\mathrm{t}, 2 \mathrm{H}, J=6.9 \mathrm{~Hz}, p-\mathrm{Ph})$, $6.89(\mathrm{t}, 2 \mathrm{H}, J=7.2 \mathrm{~Hz}, p-\mathrm{Ph}), 7.04(\mathrm{t}, J=8.1 \mathrm{~Hz}, 4 \mathrm{H}, o-\mathrm{Ph}), 7.12$ (t, $J=8.1 \mathrm{~Hz}, 4 \mathrm{H}, o-\mathrm{Ph}), 7.59$ (s, 2H, $m$-PAr), 7.60 (s, 2H, $m$-PAr), 7.67 (s, 4H, $m$-PAr). ${ }^{13} \mathrm{C}\left\{{ }^{1} \mathrm{H}\right\}$ NMR $\left(\mathrm{C}_{6} \mathrm{D}_{6}\right): \delta 32.0,32.0,32.1$, 34.4, 35.5, 35.6, 35.7, 35.8, 35.8, 39.6, 39.7, 39.8, 39.8, 69.6, 122.8, $122.8,123.2$, 123.2, 123.3, 127.2, 127.5, 127.7, 127.8, 128.9, 128.9, 132.6, 134.4, 134.4, 134.6, 134.8, $134.9(\mathrm{~m}), 142.1(\mathrm{~m}), 145.3(\mathrm{~m})$, $152.1,152.2,152.5,156.1,157.0,157.3,158.2(\mathrm{~m}), 162.8(\mathrm{~m})$. ${ }^{31} \mathrm{P}\left\{{ }^{1} \mathrm{H}\right\}$ NMR $\left(\mathrm{C}_{6} \mathrm{D}_{6}\right): \delta 174.6(\mathrm{dd}, J=220,31 \mathrm{~Hz}), 156.9(\mathrm{~d}, J$
$=266 \mathrm{~Hz}$ ). Anal. Calcd for $\mathrm{C}_{105} \mathrm{H}_{140} \mathrm{OP}_{4} \mathrm{Rh}_{2}: \mathrm{C}, 72.15 ; \mathrm{H}, 8.07$. Found: C, 71.92; H, 8.09.

Preparation of $\left[\mathrm{Rh}_{2}\left(\mu-\mathrm{HCO}_{2}\right)_{2}(\mathrm{DPCB})_{2}\right](5)$. To a solution of $2(12.5 \mathrm{mg}, 0.00741 \mathrm{mmol})$ in toluene- $d_{8}(0.5 \mathrm{~mL})$ was added formic acid $(0.6 \mu \mathrm{L}, 0.0159 \mathrm{mmol})$ at $0{ }^{\circ} \mathrm{C}$. After $10 \mathrm{~min}$, complex 5 was exclusively formed, as confirmed by NMR spectroscopy. ${ }^{1} \mathrm{H}$ NMR (toluene- $d_{8}$ ): $\delta 1.36$ (s, 36H, $p$ - $\left.t \mathrm{Bu}\right), 1.93$ (s, 72H, $o-t \mathrm{Bu}$ ), $6.74(\mathrm{t}, J=7.5 \mathrm{~Hz}, 8 \mathrm{H}, m-\mathrm{Ph}), 6.87(\mathrm{t}, J=7.5 \mathrm{~Hz}, 4 \mathrm{H}, p-\mathrm{Ph})$, $6.91(\mathrm{~d}, J=8.4 \mathrm{~Hz}, 8 \mathrm{H}, o-\mathrm{Ph}), 7.61(\mathrm{~s}, 8 \mathrm{H}, m-\mathrm{PAr}) .{ }^{31} \mathrm{P}\left\{{ }^{1} \mathrm{H}\right\} \mathrm{NMR}$ (toluene- $\left.d_{8}\right): \delta 163.2(\mathrm{~d}, J=262 \mathrm{~Hz})$.

Preparation of $\left[\mathrm{Rh}_{2}\left(\mu-\mathrm{MeCO}_{2}\right)_{2}(\mathrm{DPCB})_{2}\right](6)$. To a suspension of $2(100.0 \mathrm{mg}, 0.0571 \mathrm{mmol})$ in pentane $(1.0 \mathrm{~mL})$ was added acetic acid $(6.9 \mu \mathrm{L}, 0.120 \mathrm{mmol})$ at $0{ }^{\circ} \mathrm{C}$. The color of the suspension immediately turned from dark yellow to dark brown. After $1 \mathrm{~h}$, the precipitate was collected by filtration, washed with pentane at $0{ }^{\circ} \mathrm{C}$, and dried under vacuum to give a dark brown power of 6 (102.2 mg, 98\%). Mp: $197{ }^{\circ} \mathrm{C}$ (dec). IR (KBr): 1595, $1449 \mathrm{~cm}^{-1}$. ${ }^{1} \mathrm{H}$ NMR $\left(\mathrm{C}_{6} \mathrm{D}_{6}\right): \delta 1.39(\mathrm{~s}, 36 \mathrm{H}, p-t \mathrm{Bu}), 1.71\left(\mathrm{~s}, 6 \mathrm{H}, \mathrm{O}_{2} \mathrm{CMe}\right)$, $2.01(\mathrm{~s}, 72 \mathrm{H}, o-t \mathrm{Bu}), 6.78(\mathrm{t}, J=7.5 \mathrm{~Hz}, 8 \mathrm{H}, m-\mathrm{Ph}), 6.88(\mathrm{t}, J=$ $7.5 \mathrm{~Hz}, 4 \mathrm{H}, p-\mathrm{Ph}), 7.00(\mathrm{~d}, J=7.5 \mathrm{~Hz}, 8 \mathrm{H}, o-\mathrm{Ph}), 7.63(\mathrm{~s}, 8 \mathrm{H}$, $m$-PAr). ${ }^{13} \mathrm{C}\left\{{ }^{1} \mathrm{H}\right\}$ NMR $\left(\mathrm{C}_{6} \mathrm{D}_{6}\right): \delta 24.4,31.5,34.5,35.5,39.1,122.6$, 126.9, 128.1, 128.6, 129.6 (m), 133.3, 143.4 (m), 153.1, 157.2, 158.9 (m), $191.6(\mathrm{~m}) .{ }^{31} \mathrm{P}\left\{{ }^{1} \mathrm{H}\right\}$ NMR $\left(\mathrm{C}_{6} \mathrm{D}_{6}\right): \delta 165.9(\mathrm{~d}, J=263 \mathrm{~Hz})$. Anal. Calcd for $\mathrm{C}_{108} \mathrm{H}_{142} \mathrm{O}_{4} \mathrm{P}_{4} \mathrm{Rh}_{2}$ : C, 70.73; H, 7.80. Found: C, 70.54; H, 8.10.

Preparation of $\left[\mathbf{R h}\left(\eta^{3}-\mathbf{C}_{6} \mathbf{H}_{9}\right)(\mathrm{DPCB})\right](8)$. To a suspension of $2(49.9 \mathrm{mg}, 0.0285 \mathrm{mmol})$ in toluene $(2.5 \mathrm{~mL})$ containing 1,3 cyclohexadiene $(5.5 \mu \mathrm{L}, 0.0577 \mathrm{mmol})$ was added formic acid $(2.2$ $\mu \mathrm{L}, 0.0583 \mathrm{mmol}$ ) at room temperature. The solution immediately turned dark reddish-brown. After $0.5 \mathrm{~h}$, volatiles were removed under reduced pressure, and the residue was washed with pentane at $0{ }^{\circ} \mathrm{C}$ and dried under vacuum to give a dark reddish-brown powder of 8 (27.3 mg, 51\%). Slow diffusion of a concentrated THF solution into $\mathrm{MeOH}$ gave analytically pure crystals with the composition 8 $\cdot \mathrm{MeOH}$. Mp: $220{ }^{\circ} \mathrm{C}(\mathrm{dec}) .{ }^{1} \mathrm{H}$ NMR $\left(\mathrm{C}_{6} \mathrm{D}_{6}\right): \delta 1.41$ (s, 18H, p- $t \mathrm{Bu}), 1.71(\mathrm{~s}, 18 \mathrm{H}, o-t \mathrm{Bu}), 1.91$ (s, 18H, o- $t \mathrm{Bu}), 2.26$ (br, $\left.4 \mathrm{H}, \mathrm{CHCH}_{2} \mathrm{CH}_{2}\right), 4.79\left(\mathrm{~m}, 2 \mathrm{H}\right.$, allyl $\left.\mathrm{H}_{\text {syn }}\right), 5.69$ (td, $J=6.5$, $2.6 \mathrm{~Hz}, 1 \mathrm{H}$, allyl $\left.\mathrm{H}_{\text {central }}\right), 6.81(\mathrm{t}, J=7.4 \mathrm{~Hz}, 4 \mathrm{H}, m-\mathrm{Ph}), 6.90(\mathrm{t}$, $J=7.4 \mathrm{~Hz}, 2 \mathrm{H}, p-\mathrm{Ph}), 7.05(\mathrm{~d}, J=7.2 \mathrm{~Hz}, 4 \mathrm{H}, o-\mathrm{Ph}), 7.65(\mathrm{~s}$, $2 \mathrm{H}, m$-PAr), 7.70 (s, 2H, $m$-PAr). ${ }^{13} \mathrm{C}\left\{{ }^{1} \mathrm{H}\right\}$ NMR $\left(\mathrm{C}_{6} \mathrm{D}_{6}\right): \delta 23.0$, 29.8, 31.7, 33.6, 34.4, 35.4, 39.1, 39.1, 68.6 (dd, $J=36,9 \mathrm{~Hz})$, $101.2(\mathrm{~m}, J=3 \mathrm{~Hz}), 122.5,122.8,127.5,128.5,134.0,135.4(\mathrm{~m})$, 144.7 (dd, $J=55,32 \mathrm{~Hz}), 151.5,156.0,156.1,167.5$ (ddd, $J=$ $34,30,5 \mathrm{~Hz}) .{ }^{31} \mathrm{P}\left\{{ }^{1} \mathrm{H}\right\} \operatorname{NMR}\left(\mathrm{C}_{6} \mathrm{D}_{6}\right): \delta 165.4(\mathrm{~d}, J=241 \mathrm{~Hz})$. 
Anal. Calcd for $\mathrm{C}_{59} \mathrm{H}_{81} \mathrm{OP}_{2} \mathrm{Rh}(\mathbf{8} \cdot \mathrm{MeOH})$ : C, 72.97; H, 8.41. Found: C, 72.70; H, 8.24.

Preparation of $\left[R_{2}(\mu-\kappa P, P ; \kappa P, C-D P C B)(C O)_{4}\right](9)$. A suspension of $2(71.2 \mathrm{mg}, 0.0411 \mathrm{mmol})$ in pentane $(8.0 \mathrm{~mL})$ was degassed by freeze-pump-thaw cycles, and carbon monoxide ( 1 atm) was introduced from a CO balloon. The dark red suspension changed to a dark brown solution. Slow evaporation of the solvent under the flow of $\mathrm{CO}$ gas at room temperature for 2 days formed dark brown crystals with the composition $\mathbf{8} \cdot \mathrm{C}_{5} \mathrm{H}_{12}(24.0 \mathrm{mg}, 55 \%)$. $\mathrm{Mp}:>300{ }^{\circ} \mathrm{C}$. IR (KBr): 2033, 2008, 1977, $1962 \mathrm{~cm}^{-1} .{ }^{1} \mathrm{H}$ NMR (toluene- $\left.d_{8}\right): \delta 1.27(\mathrm{~s}, 18 \mathrm{H}, p-t \mathrm{Bu}), 1.77(\mathrm{~s}, 18 \mathrm{H}, o-t \mathrm{Bu}), 1.85(\mathrm{~s}$, $18 \mathrm{H}, o-t \mathrm{Bu}), 6.71-6.81(\mathrm{~m}, 10 \mathrm{H}, \mathrm{Ph}), 7.33$ (s, 2H, $m$-PAr), 7.47 (s, 2H, $m$-PAr). ${ }^{13} \mathrm{C}\left\{{ }^{1} \mathrm{H}\right\}$ NMR (toluene- $\left.d_{8}\right): \delta 31.3,35.2,35.3,39.9$, $40.0,123.1,123.6,127.2,128.0,128.3,131.3(\mathrm{td}, J=13,5 \mathrm{~Hz})$, $132.3,133.0$ (dd, $J=8,7 \mathrm{~Hz}), 144.4$ (t, $J=8 \mathrm{~Hz}), 152.4,157.6$, 158.5, 194.7 (dt, $J=74,28 \mathrm{~Hz}$ ). ${ }^{31} \mathrm{P}\left\{{ }^{1} \mathrm{H}\right\}$ NMR (toluene- $d_{8}$ ): $\delta$ 152.9 (dd, $J=151,44 \mathrm{~Hz}$ ). Anal. Calcd for $\mathrm{C}_{61} \mathrm{H}_{80} \mathrm{O}_{4} \mathrm{P}_{2} \mathrm{Rh}_{2}$ $\left(8 \cdot \mathrm{C}_{5} \mathrm{H}_{12}\right)$ : C, 63.98; H, 7.04. Found: C, 63.60; H, 6.86.

Preparation of $\left[\mathrm{Rh}_{2}(\mu-\mathrm{CO})_{2}(\mathrm{DPCB})_{2}\right](\mathbf{1 0})$. A solution of 2 (150.8 $\mathrm{mg}, 0.086 \mathrm{mmol})$ in THF $(4.0 \mathrm{~mL})$ was degassed by freeze-pump-thaw cycles, and carbon monoxide (1 atm) was introduced from a $\mathrm{CO}$ balloon. The solution immediately turned dark brown. The mixture was stirred for $30 \mathrm{~min}$ at room temperature under a $\mathrm{CO}$ atmosphere. After purging the $\mathrm{CO}$ gas from the solution, volatiles were removed under vacuum, and the residue was washed with $\mathrm{Et}_{2} \mathrm{O}$ at $0{ }^{\circ} \mathrm{C}$ and dried under vacuum to give a dark brown powder of $\mathbf{1 0}(111.8 \mathrm{mg}, 73 \%)$. Recrystallization from THF and $\mathrm{MeOH}$ formed single crystals, suitable for $\mathrm{X}$-ray structural analysis. IR (KBr): $1766 \mathrm{~cm}^{-1} .{ }^{1} \mathrm{H}$ NMR $\left(\mathrm{C}_{6} \mathrm{D}_{6}\right): \delta 1.35(\mathrm{~s}, 36 \mathrm{H}, p-t \mathrm{Bu})$, $1.82(\mathrm{~s}, 72 \mathrm{H}, o-t \mathrm{Bu}), 6.80(\mathrm{~m}, 12 \mathrm{H}, m$ - and $p-\mathrm{Ph}), 6.96(\mathrm{~d}, J=6.9$ $\mathrm{Hz}, 4 \mathrm{H}, o-\mathrm{Ph}), 7.61(\mathrm{~s}, 8 \mathrm{H}, m-\mathrm{PAr}) .{ }^{13} \mathrm{C}\left\{{ }^{1} \mathrm{H}\right\} \mathrm{NMR}\left(\mathrm{C}_{6} \mathrm{D}_{6}\right): \delta 31.6$,
34.5, 35.3, 39.3, 122.8, 128.1, 128.5, 132.6, $148.6(\mathrm{~m}), 151.7,156.8$, $172.1(\mathrm{t}, J=28 \mathrm{~Hz}) \cdot{ }^{31} \mathrm{P}\left\{{ }^{1} \mathrm{H}\right\} \mathrm{NMR}\left(\mathrm{C}_{6} \mathrm{D}_{6}\right): \delta 173.9(\mathrm{~d}, J=235$ $\mathrm{Hz})$.

X-ray Diffraction Studies. All measurements were performed on a Rigaku Mercury CCD diffractometer with graphite-monochromated Mo K $\alpha$ radiation $(\lambda=0.71070 \AA)$. The intensity data were collected at $173 \mathrm{~K}$ and corrected for Lorentz and polarization effects and absorption (numerical). The structures were solved by DIRDIF99 and refined on $F^{2}$ for all reflections (SHELXL-97). ${ }^{20}$ All non-hydrogen atoms were refined anisotropically. The $\mu-\mathrm{H}$ ligands in $\mathbf{3}$ and $\mathbf{4}$ were located from the differential Fourier maps and refined isotropically. The other hydrogen atoms were placed using AFIX instructions. Full crystallographic data have been deposited with the Cambridge Crystallographic Data Centre: CCDC No. $671945\left(2 \cdot\left(2 \mathrm{C}_{5} \mathrm{H}_{12}\right)\right), 671947\left(3 \cdot \mathrm{Et}_{2} \mathrm{O}\right), 671948$ (4), 671949 $\left(\mathbf{9} \cdot \mathrm{C}_{5} \mathrm{H}_{12}\right), 671950(\mathbf{1 0})$. A summary of the crystallographic data is given in Table 1.

Acknowledgment. This work was supported by Grantsin-Aid for Scientific Research on Priority Areas (No. 18064010, "Synergy of Elements") from the Ministry of Education, Culture, Sports, Science, and Technology, Japan.

Supporting Information Available: Crystallographic data of $\mathbf{2} \cdot\left(2 \mathrm{C}_{5} \mathrm{H}_{12}\right), \mathbf{3} \cdot \mathrm{Et}_{2} \mathrm{O}, \mathbf{4}, \mathbf{9} \cdot \mathrm{C}_{5} \mathrm{H}_{12}$, and $\mathbf{1 0}$ in cif format. This material is available free of charge via the Internet at http://pubs.acs.org.

\section{OM8010799}

(20) Sheldrick, G. M. SHELX-97; University of Göttingen: Germany, 1997. 